International Journal of Current Advanced Research

ISSN: O: 2319-6475, ISSN: P: 2319 - 6505, Impact Factor: SJIF: 5.995

Available Online at www.journalijcar.org

Volume 6; Issue 3; March 2017; Page No. 2604-2607

DOI: http://dx.doi.org/10.24327/ijcar.2017.2607.0055

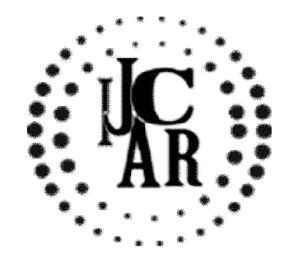

Research Article

\title{
A POWERFUL BINDING OF PLANT BIOACTIVE COMPOUND SWERTIAMARIN TO OMPF PORINS RESEMBLING ANTIBIOTICS-AN IN SILICO STUDY
}

\author{
Gopal Madhana Vigneshwari., Perumal Sasidharan and Raja Mohmed Beema Shafreen*
}

Molecular and Nanomedicine Research Unit, Centre for Nanoscience and Nanotechnology (CNSNT), Sathyabama

University, Chennai, India

\begin{tabular}{|c|c|}
\hline A R T I C L E I N F O & A $\mathbf{E}$ \\
\hline Article History: & \multirow{4}{*}{$\begin{array}{l}\text { Antibiotic resistance of the bacteria leads to Multi Drug Resistance (MDR) strain which is } \\
\text { achieved mainly by the presence of Outer membrane Proteins (OMP) in the bacteria. } \\
\text { Swertiamarin is an active compound isolated from Enicostemma axillare, a herb which was } \\
\text { already proved to have antimicrobial activity. Also the herb was used to treat diseases like } \\
\text { skin disease, intermittent fever, helminthiasis, tumors, diabetes mellitus, rheumatism, } \\
\text { abdominal ulcer, hernia, swelling, itching, and insect poisoning. In this study, in silico } \\
\text { analysis of swertamarin interaction was studied by docking the compound with Salmonella } \\
\text { typhi and Escherichia coli OmpF porins. The molecular information helps in checking the } \\
\text { efficiency of the compound as antibacterial agent and a way to design effective drugs from } \\
\text { the compound. }\end{array}$} \\
\hline $\begin{array}{l}\text { Received } 18^{\text {th }} \text { December, } 2016 \\
\text { Received in revised form } 16^{\text {th }} \text { January, } 2017 \\
\text { Accepted } 26^{\text {th }} \text { February, } 2017 \\
\text { Published online } 28^{\text {th }} \text { March, } 2017\end{array}$ & \\
\hline Key words: & \\
\hline MDR, OMP, porins & \\
\hline
\end{tabular}

Copyright $₫ 2017$ Raja Mohmed Beema Shafreen. This is an open access article distributed under the Creative Commons Attribution License, which permits unrestricted use, distribution, and reproduction in any medium, provided the original work is properly cited.

\section{INTRODUCTION}

Around 25 to $30 \%$ of most of the organisms gene encode integral membrane proteins ${ }^{[1]}$ and they are the key target of many pharmacological drugs. Porin is a major outer membrane protein (OMP) of most of the gram negative bacteria and a few gram positive bacteria.
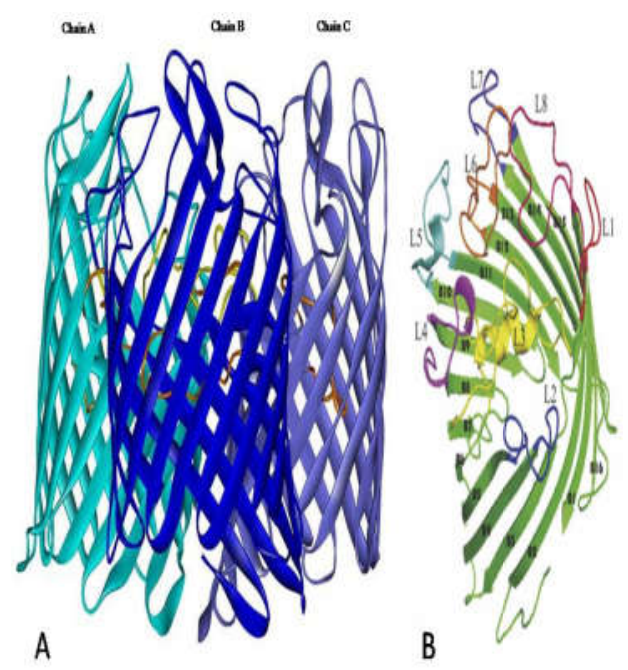

Figure $^{1(7)}$ A) Cartoon representation of OmpF homotrimer B) OmpF monomer showing loops and beta strands information

*Corresponding author: Raja Mohmed Beema Shafreen, Molecular and Nanomedicine Research Unit, Centre for Nanoscience and Nanotechnology (CNSNT), Sathyabama University, Chennai, India
Porins function in allowing the passive diffusion of small, polar molecules like water, ions, glucose, and other nutrients as well as waste products (600-700 Da). In particular, gram negative bacteria is deficient in expressing OmpF when exposed to antibiotics which leads to develop resistant against that antibiotics mainly $\beta$ - lactam antibiotics $[\mathbf{2 , 3 , 4 , 5 , 6 ]}$. The structure of OMPF is a homotrimer and each monomer forms water filled open channels in the outer membrane that allows the movement of small hydrophilic solutes such as amino acids, monosaccharides and ions ${ }^{[7]}$ (Figure 1). Also, OmpF porins provide multi drug resistance to the bacteria by reducing the antibiotic permeability through altered pore properties which lowers the susceptibility of the bacteria for antibiotics ${ }^{[8]}$. There is always a need of efficient drugs to treat diseases. The study of OmpF antibiotic complexes will provide a better understanding about the molecular level interaction of the antibiotic with the porin and in future it helps in designing potent drugs to eradicate pathogenic diseases ${ }^{[8]}$.Then in silico study of ompf antibiotic. India is endowed with a rich wealth of Medicinal plants. The increasing failure, chemotherapeutics and antibiotic resistance exhibited by pathogenic microbial infections agents have led to the screening of several medicinal plants. Phytochemical is one such biologically active compound used effectively in treating human diseases in an idea to develop more effective and less toxic medicines. Plant derived drug serves as a prototype to increase body's natural resistance to diseases which is the expected remedy of any disease. Enicostemma axillare (Lam) A. Raynal (Gentianceae) is commonly known as 'Vellargu' in Tamil. It is an herb, $50 \mathrm{~cm}$ inch in height 
widely distributed throughout India up to $450 \mathrm{MSL}$. It is a very bitter plant and used in indigenous medicines in treatment of fever and as bitter tonic. And the other benefits of the plant in treating skin disease, intermittent fever, helminthiasis and tumors, diabetes mellitus, rheumatism, abdominal ulcer, hernia, swelling, itching, and insect poisoning have been reported ${ }^{[9,10]}$. Though the plant has so many medicinal properties, swertiamarin (Figure 2) is one identified potent compound isolated mainly from the aerial part of the plant ${ }^{[11,12]}$. Earlier, column chromatography over silica gel is performed to isolate swertiamarin but recently, Centrifugal Partition Chromatography is been successfully used for the separation of the compound from the crude extract of the plant ${ }^{[13,14]}$. In the present study, S. typhi OmpF (3NSG) and E. coli OmpF (2OMF) is docked with swertiamarin in order to find the antibacterial activity of the compound and the interacting residues involved in the influx of the compound through the porins ${ }^{[15]}$. This gives insight to the specificity of OmpF binding with swertiamarin in different organism porins namely E. coli and S. typhi.

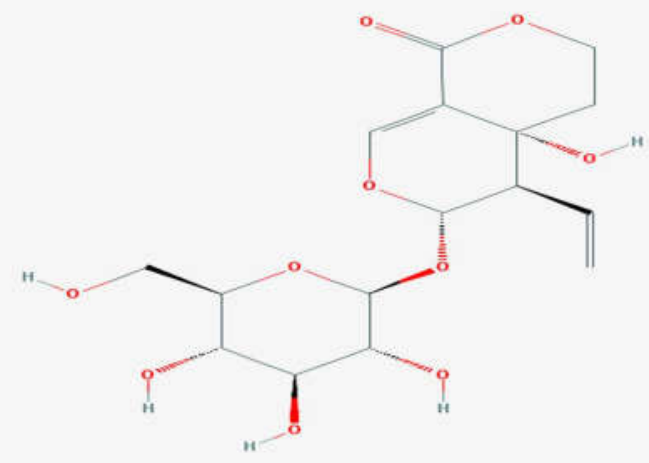

Figure 2 Structure of swertiamarin

\section{MATERIALS AND METHODS}

\section{Selection of Target and Ligand}

OmpF porin structures (3NSG and 2OMF) were retrieved from the protein databank (PDB) (www.rcsb.org/). Active site of the target protein was predicted using CASTp (http://sts.bioe.uic.edu/castp/).
Swertiamarin (CID 442435) compound was retrieved from PubChem database (pubchem.ncbi.nlm.nih.gov).

\section{Receptor Preparation and Docking}

The heteroatom, water molecules and ligands were removed using Discovery Studio 4.1 before docking. Superimposition of $3 \mathrm{NSG}$ and 2OMF was done in SuperPose online server (http://wishart.biology.ualberta.ca/superpose/). The docking calculation for $S$. typhi OmpF and E. coli OmpF with ligand (swertiamarin) was performed with online Molecular docking server (http://www.dockingserver.com/web) and stand-alone AutoDock 4.0.1. A grid of 120, 120 and 120 points in $x, y$ and $\mathrm{z}$ directions in AutoDock was built to cover the entire protein.

\section{RESULTS}

\section{Molecular docking}

Molecular docking was successfully completed between target receptor and the selected compound named swertiamarin (CID 442435).

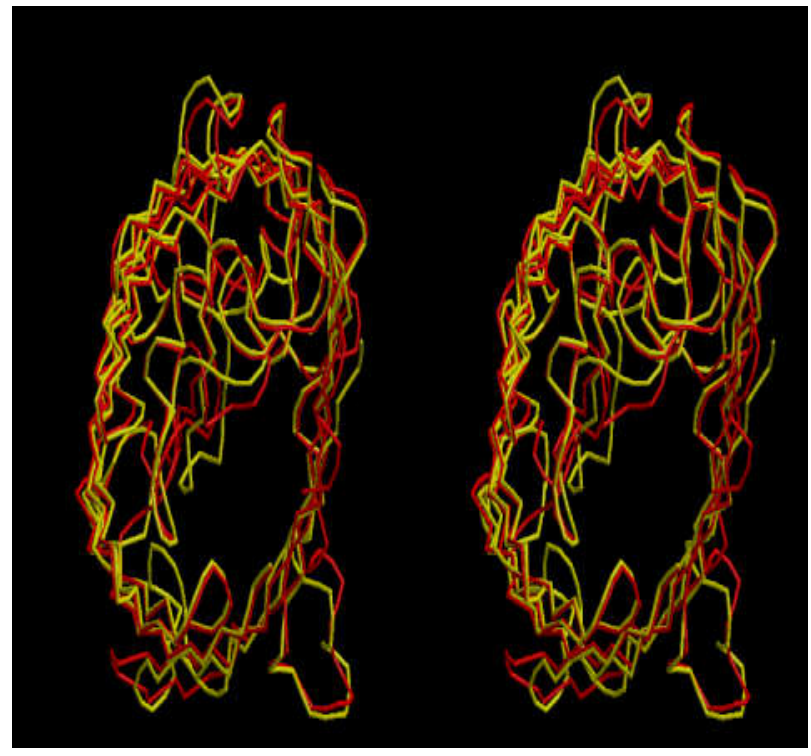

Figure 3 Superimposition of 2OMF and 3NSG by SuperPose server

Table 1 Active site residues calculated for 3NSG and 2OMF by CASTp server

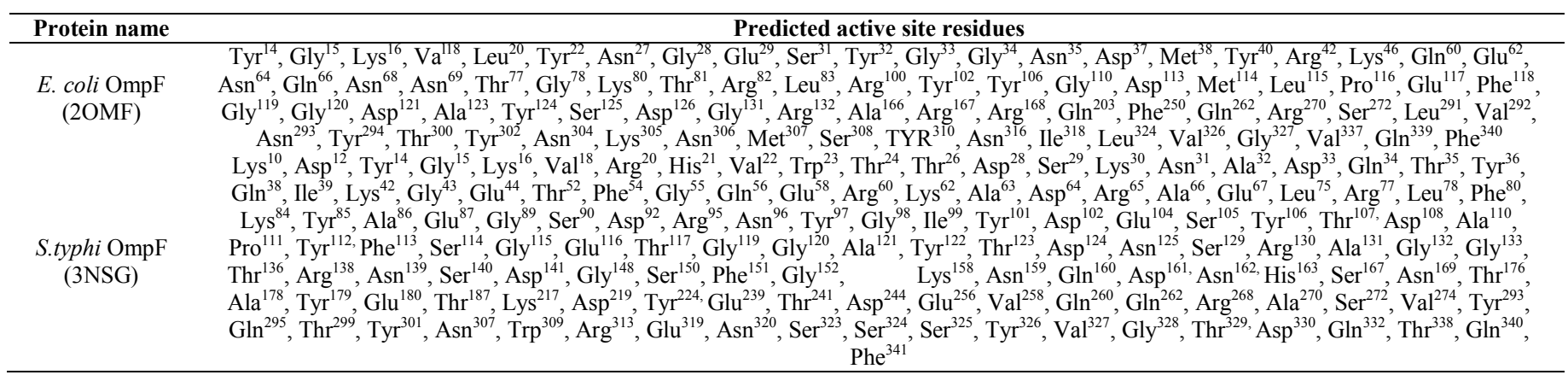

Table 2 Docking calculations of S. typhi and E.coli OmpF porins

\begin{tabular}{|c|c|c|c|c|c|}
\hline $\begin{array}{l}\text { Protein } \\
\text { (PDBID) }\end{array}$ & $\begin{array}{l}\text { Binding } \\
\text { Energy }\end{array}$ & $\begin{array}{l}\text { Inhibition } \\
\text { Constant Ki }\end{array}$ & $\begin{array}{c}\text { Interaction } \\
\text { surface }\end{array}$ & Binding residues & $\begin{array}{c}\text { Common active site residues of } \\
\text { predicted and actual binding } \\
\text { residues }\end{array}$ \\
\hline $\begin{array}{l}\text { S. typhi OmpF } \\
\text { 3NSG }\end{array}$ & $\begin{array}{c}-4.50 \\
\mathrm{kcal} / \mathrm{mol}\end{array}$ & 499.77 uM & 690.523 & $\begin{array}{c}\operatorname{Tyr}^{101}, \text { Asp }^{108}, \text { Arg }^{20}, \text { Gly }^{15}, \text { Tyr }^{14}, \\
\operatorname{Arg}^{130}, \operatorname{Arg}^{77}, \text { Glu }^{56}, \text { Glu }^{58}, \text { Gln }^{38}, \text { Tyr }^{97}\end{array}$ & $\begin{array}{l}\operatorname{Tyr}^{101}, \operatorname{Asp}^{108}, \operatorname{Arg}^{20}, \text { Gly }^{15}, \text { Tyr }^{14}, \\
\operatorname{Arg}^{130}, \operatorname{Arg}^{77}, \underset{\operatorname{Tyr}^{97}}{\operatorname{Gl}^{56}}, \text { Glu }^{58}, \text { Gln }^{38},\end{array}$ \\
\hline $\begin{array}{l}\text { E. coli } \mathrm{OmpF} \\
\text { 2OMF }\end{array}$ & $\begin{array}{c}-5.14 \\
\mathrm{kcal} / \mathrm{mol}\end{array}$ & $169.34 \mathrm{uM}$ & 658.387 & $\begin{array}{c}\text { Phe }^{118}, \text { Asp }^{121}, \text { Tyr }^{124}, \text { Leu }^{291}, \text { Val }^{292} \\
\text { Val }^{100}, \text { Gln }^{80}, \text { Tyr }^{32}, \text { Arg }^{163}\end{array}$ & $\begin{array}{l}\text { Phe }^{118}, \text { Asp }^{121}, \text { Tyr }^{124}, \text { Leu }^{291} \\
\operatorname{Val}^{292}, \mathrm{Val}^{100}, \mathrm{Gln}^{80}, \mathrm{Tyr}^{32}\end{array}$ \\
\hline
\end{tabular}


The active sites of the target structures were predicted using CASTp server and the results were tabulated (Table 1). The binding energy $(\Delta \mathrm{G})$ was found to be $-6.87 \mathrm{kcal} / \mathrm{mol}$ and -7.95 $\mathrm{kcal} / \mathrm{mol}$ for $S$. typhi $\mathrm{OmpF}$ and $E$. coli OmpF respectively. Inhibition constant was calculated to be $499.77 \mathrm{uM}$ and $169.34 \mathrm{uM}$ for $S$. typhi OmpF and E. coli OmpF respectively (Table 2). Interacting residues in the receptor was studied with Discovery studio 4.1 (Table 3 and 4). Superimposition of 2OMf and $3 \mathrm{NSG}$ was done in SuperPose server showing $54.9 \%$ identity and $70.2 \%$ similarity (Figure 3 ).

Table 3 Structure information of the interacting residues in $3 \mathrm{NSG}$

\begin{tabular}{cc}
\hline $\begin{array}{c}\text { Interacting amino acids in } \\
\text { S. typhi OmpF }\end{array}$ & $\begin{array}{c}\text { Structure information of } \\
\text { the interacting residues in } \\
\text { S. typhi OmpF (3NSG) }\end{array}$ \\
\hline $\mathrm{Tyr}^{101}, \mathrm{Asp}^{108}$ & Loop L3 \\
$\mathrm{Arg}^{130}$ & Beta strand $\beta 7$ \\
$\mathrm{Arg}^{20}, \mathrm{Gly}^{15}, \mathrm{Tyr}^{14}$ & Beta strand $\beta 2$ \\
$\mathrm{Arg}^{77}$ & Beta strand $\beta 5$ \\
$\mathrm{Glu}^{56}, \mathrm{Glu}^{58}$ & Beta strand $\beta 4$ \\
$\mathrm{Gln}^{38}$ & Loop L1 \\
$\mathrm{Tyr}^{97}$ & Beta strand $\beta 6$ \\
\hline
\end{tabular}

Table 4 Structure information of the interacting residues in $2 \mathrm{OMF}$

\begin{tabular}{cc}
\hline $\begin{array}{c}\text { Interacting amino acids in } \\
\text { E.coli OmpF }\end{array}$ & $\begin{array}{c}\text { Structure information of the } \\
\text { interacting residues in } \boldsymbol{E} \text {. coli } \\
\text { OmpF (2OMF) }\end{array}$ \\
\hline $\mathrm{Phe}^{118}, \mathrm{Asp}^{121}, \mathrm{Tyr}^{124}, \mathrm{Val}^{100}$ & Loop L3 \\
$\mathrm{Gln}^{80}$ & Beta strand $\beta 5$ \\
$\mathrm{Tyr}^{32}$ & Loop L1 \\
$\mathrm{Leu}^{291}, \mathrm{Val}^{292}$ & Beta strand $\beta 15$ \\
$\mathrm{Arg}^{163}$ & Loop L4 \\
\hline
\end{tabular}

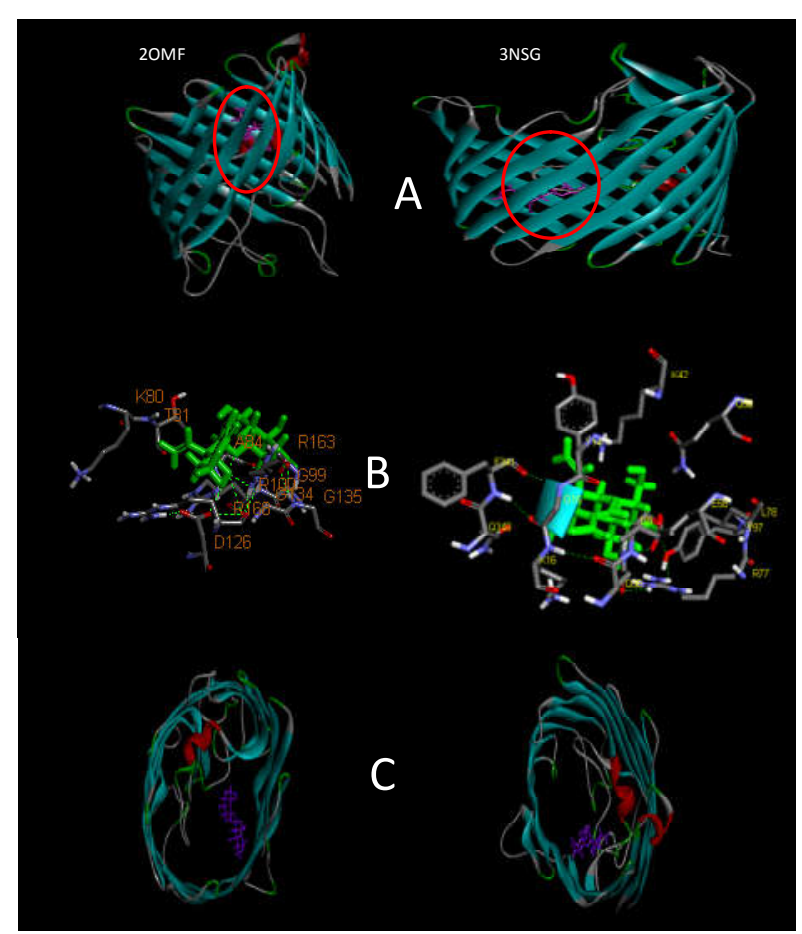

Figure 4 A) Side view of docked swertiamarin with 2OMF and 3NSG B) Docked pose of swertiamarin with 2OMF and 3 NSG showing aminoacid residues $\mathrm{C}$ ) Top view of docked swertiamarin with $2 \mathrm{OMF}$ and $3 \mathrm{NSG}$

\section{Binding of swertiamarin in an antibiotic pattern to S. typhi and $E$. coli OmpF}

In $S$. typhi OmpF, the compound interacted with the following aminoacid residues $\mathrm{Tyr}^{101}, \mathrm{Asp}^{108}, \mathrm{Arg}^{20}, \mathrm{Gly}^{15}, \mathrm{Tyr}^{14}, \mathrm{Arg}^{130}$,
$\mathrm{Arg}^{77}, \mathrm{Glu}^{56}, \mathrm{Glu}^{58}, \mathrm{Gln}^{38}$ and $\mathrm{Tyr}^{97}$ in which $\mathrm{Asp}^{108}, \mathrm{Arg}^{20}$, $\mathrm{Arg}^{130}, \mathrm{Arg}^{77}$ and $\mathrm{Gln}^{38}$ were reported binding residues in $E$.' coli ompF with ampicillin [16], moxifloxacine ${ }^{[17]}$ and enrofloxacin ${ }^{[18]}$ (Figure 4). S. typhi and E. coli OmpF share higher percentage of sequence similarity ${ }^{[7]}$. In comparison with $E$. coli sequence, Leu $^{20}$ (from strand $\beta 2$ ) in $E$. coli sequence is replaced by Arg (from strand $\beta 2$ ) and $\mathrm{Met}^{38}$ (from loop L1) in E. coli sequence is replaced by Glu (from loop L1) in $S$. typhi which on strong binding again with swertiamarin indicates the same efficiency of the replaced residues in binding with the compound. $\mathrm{Leu}^{20}$ and $\mathrm{Gln}^{38}$ are known for providing the hydrophobic interaction of the beta lactam antibiotics in E. coli OmpF. Interestingly ${ }^{[7]} \mathrm{Asp}^{108}$ (from loop L3), $\mathrm{Arg}^{20}$ (from strand $\beta 2$ ) and $\mathrm{Arg}^{77}$ (from strand $\beta 5)$ residues in the beta strand, lines from extracellular to intracellular constriction zone and the binding of the compound to these residues in a particular fashion paves way for the translocation of the compound in to the porin.

In E. coli OmpF, swertiamarin interacts with $\mathrm{Phe}^{118}$, $\mathrm{Asp}^{121}$, $\mathrm{Tyr}^{124}, \mathrm{Leu}^{291}, \mathrm{Val}^{292}, \mathrm{Val}^{100}, \mathrm{Gln}^{80}, \mathrm{Tyr}^{32}$ and $\mathrm{Arg}^{163}$ in which $\mathrm{Tyr}^{32}$, $\mathrm{Phe}^{118}$, $\mathrm{Asp}^{121}, \mathrm{Tyr}^{124}$, Leu ${ }^{291}$ and $\mathrm{Val}^{292}$ are common reported binding residues of $E$. coli OmpF with ampicillin ${ }^{[19]}$. $\mathrm{Arg}^{163}$ (from loop L4) is present only in E. coli OmpF and is known for binding with antibiotics which is replaced with $\mathrm{His}^{163}$ (from loop L4) in S. typhi OmpF ${ }^{[16]}$. Asp ${ }^{121}$ plays important role in the binding of colicin to OmpF (Bredin 2003) and the Asp ${ }^{121}$ mutant E. coli OmpF showed ${ }^{[20]} \sim 20 \%$ increase in carbenicillin susceptibility.

\section{CONCLUSION}

Even though porins belong to general diffusion category, they do not transport molecules without any specificity inside the channel. The molecule to be transported through the channel makes specific interactions with the residues in the constriction zone which actually paves way to the transport of the particular molecule. In this study, the interaction of swertiamarin with E. coli OmpF and S.typhi OmpF was studied to explore the binding configuration of a swertiamarin compound to both porins. Despite the fact that S. typhi OmpF and $E$. coli $\mathrm{OmpF}$ share around $70.2 \%$ similarity, the property of the porin in allowing the same swertiamarin molecule differs. Based on the results obtained from the interaction study swertiamarin a phytochemical exhibit almost similar pattern of binding configuration with that of well-known antibiotics. Since E. axillare is known for its medicinal properties, the activity of swertiamarin comparable with antibiotics shows the efficiency of the compound as antibacterial agent. Being a plant derived compound it is less harmful and the information on the compound binding serve as a key for next generation medicine since the compound has many chemotherapeutic properties in treating diseases.

\section{Acknowledgement}

Equal contribution was made by the co-author and a request was made to kindly consider as first author. DST-INSPIRE and UGC-BSR-RFSMS for fellowship.

\section{Reference}

1. Wallin, E., von Heijne, G. 1998. Genome-wide analysis of integral membrane proteins from eubacterial, archaean, and eukaryotic organisms. Protein Sci. 7, 1029- 1038. 
2. Heinze-Krauss, I., Angehrn, P., Charnas, R.L., Gubernator, K., Gutknecht, E.M. 1998. Structure based design of beta-lactamase inhibitors Synthesis and evaluation of bridged monobactams. J Med Chem. 41, 3961-71.

3. Normark, B.H., Normark, S. 2002. Evolution and spread of antibiotic resistance. J Intern Med. 252, 91106.

4. Poole, K. 2002. Outer membranes and efflux: the path to multidrug resistance in Gram negative bacteria. Curr Pharm Biotechnol. 3, 77-98.

5. Li, X.Z., Nikaido, H. 2004. Efflux-mediated drug resistance in bacteria. Drugs. 64, 159-204.

6. Benz, R. 2004. Wiley-VCH, ed. Role of bacterial porins in antibiotic susceptibility of gram-negative bacteria in Bacterial and Eukaryotic Porin. 41-59.

7. Balasubramaniam, D., Arockiasamy, A., Kumar, P.D., Sharma, A., Krishnaswamy, S. 2012. Asymmetric pore occupancy in crystal structure of OmpF porin from Salmonella typhi. J of Str Biol. 178, 233-244.

8. Kojima, S., Nikaido, H. 2013. Permeation rates of penicillins indicate that Escherichia coli porins function principally as nonspecific channels. Proc Natl Acad Sci U S A. 110, E2629-2634.

9. Vaidya, H., Goyal, R.K., Cheema, S.K. 2013. Antidiabetic Activity of Swertiamarin is due to an Active Metabolite, Gentianine, that Upregulates PPAR- $\gamma$ Gene Expression in 3T3-L1 cells. Phytother Res. 27,624627.

10. Tushar, P. 2013. Swertiamarin: An Active Lead from Enicostemma littorale Regulates Hepatic and Adipose Tissue Gene Expression by Targeting PPAR$\gamma$ and Improves Insulin Sensitivity in Experimental NIDDM Rat Mode. Evid Based Complement Alternat Med. 2013, 358673.

11. Jaishree, V., Badami, S. 2010. Antioxidant and hepatoprotective effect of swertiamarin from Enicostemma axillare against D-galactosamine induced acute liver damage in rats. J Ethnopharmacol. 130, 103-106.
12. Rana, V.S, Dhanani, T., Kumar, S. 2012. Improved and rapid HPLC-PDA method for identification and quantification of swertiamarin in the aerial parts of Enicostema axillare. Malaysian J Pharma Sc. 10, 1-10.

13. Kim, C.Y., Ahn, M.J., Kim, J. 2006. Preparative isolation of mangiferin from Anemarrhena asphodeloides rhizomes by Centrifugal Partition Chromatography. J Liq Chromatogr Relat Tech. 29, 869-875.

14. Cheong, J.H., Kim, C.Y., Kim, J. 2007. Preparative isolation and purification of sinomenine from Sinomenium acutum by centrifugal partition chromatography. J Sep Sci. 30, 2105-2108.

15. James, C.E., Mahendran, K.R., Molitor, A., Bolla, J.M., Bessonov, A.N., Winterhalter, M., Pagès, J. 2009. How $\beta$-Lactam Antibiotics Enter Bacteria: A Dialogue with the Porins. PLoS One. 4, e5453.

16. Kumar, A., Hajjar, E., Ruggerone, P., Ceccarelli, M. 2010. Molecular Simulations Reveal the Mechanism and the Determinants for Ampicillin Translocation through OmpF. J Phys Chem B. 114, 9608-9616.

17. Hajjar, E., Kumar, A., Ruggerone, P., Ceccarelli, M. 2010.Investigating reaction pathways in rare events simulations of antibiotics diffusion through protein channels. J Mol Model. 16, 1701-1708.

18. Mahendran, K.R. 2010. Molecular basis of enrofloxacin translocation through OmpF, an outer membrane channel of Escherichia coli when binding does not imply translocation. J Phys Chem. B. 114, 5170-5179.

19. Niveshika., Verma,E., Mishra, A.K., Singh, A.K., Singh, V.K. 2013. Structural Elucidation and Molecular Docking of a Novel Antibiotic Compound from Cyanobacterium Nostoc sp. MGL001. Evi Comp and Alt Med. 7, 1899.

20. Bredin, J. 2003. Colicins, Spermine and Cephalosporins: A Competitive Interaction With The Ompf Eyelet. Biochem J. 376, 245-252.

21. Brigitte, K., Ziervogel., Roux, B. 2013. The Binding of Antibiotics in OmpF Porin. Structure. 21, 76-87.

\section{Please cite this article in press as:}

Gopal Madhana Vigneshwari et al(2017), 'A Powerful Binding Of Plant Bioactive Compound Swertiamarin To Ompf Porins Resembling AntibioticAn In Silico Study', International Journal of Current Advanced Research, 6(3), pp. 2604-2607.

http://dx.doi.org/10.24327/ijcar.2017. 2607.0055 